\title{
The HTLV-1 hbz antisense gene indirectly promotes tax expression via down-regulation of p30-II mRNA
}

\author{
Gunjan Choudhary, Daniel Rauch, Lee Ratner* \\ From 15th International Conference on Human Retroviruses: HTLV and Related Viruses \\ Leuven and Gembloux, Belgium. 5-8 June 2011
}

Human T-cell leukemia virus type 1 (HTLV-1) basic leucine zipper factor (HBZ) is transcribed from the antisense genomic DNA strand and functions differently in its RNA and protein forms. To distinguish between the roles of hbz mRNA and HBZ protein, we generated mutants in a proviral clone that specifically disrupt the $\mathrm{hbz}$ gene product. A proviral clone with a splice acceptor mutation that disrupts expression of the predominant hbz mRNA resulted in lower levels of tax mRNA. Heterologous hbz expression restored Tax activity in cells expressing this mutant clone. In contrast, proviral mutants that disrupt only HBZ protein did not affect levels of tax mRNA. Expression of hbz resulted in lower levels of p30II mRNA. Mutation of p30II overcame the effects of the splice acceptor mutation of hbz, and restored tax expression. Thus, there is a complex interplay of viral regulatory proteins controlling levels of HTLV-1 gene expression. The pathogenic role of HBZ alone or combined with Tax is currently under study in transgenic mice, and will be discussed.

Submit your next manuscript to BioMed Central and take full advantage of:

- Convenient online submission

- Thorough peer review

- No space constraints or color figure charges

- Immediate publication on acceptance

- Inclusion in PubMed, CAS, Scopus and Google Scholar

- Research which is freely available for redistribution

\section{Biomed Central}

(c) 2011 Choudhary et al; licensee BioMed Central Ltd. This is an open access article distributed under the terms of the Creative Commons Attribution License (http://creativecommons.org/licenses/by/2.0), which permits unrestricted use, distribution, and reproduction in any medium, provided the original work is properly cited. 